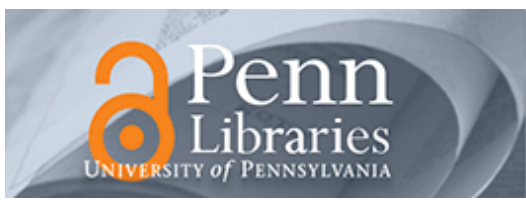

University of Pennsylvania
ScholarlyCommons

Department of Anthropology Papers

Department of Anthropology

1964

\title{
Kūch u Balūch and Ichthyophagi
}

Brian Spooner

University of Pennsylvania, spooner@sas.upenn.edu

Follow this and additional works at: http://repository.upenn.edu/anthro_papers

Part of the Anthropology Commons

\section{Recommended Citation}

Spooner, B. (1964). Kūch u Balūch and Ichthyophagi. Iran, 2 53-67. Retrieved from http://repository.upenn.edu/anthro_papers/138

This paper is posted at ScholarlyCommons. http://repository.upenn.edu/anthro_papers/138

For more information, please contact libraryrepository@pobox.upenn.edu. 


\title{
Kūch u Balūch and Ichthyophagi
}

\begin{abstract}
An enquiry into the present condition of the Persian province of Baluchistan, its antecedents and potentialities
\end{abstract}

\section{Disciplines}

Anthropology | Social and Behavioral Sciences 


\title{
$\kappa \bar{U} C H U$ BALŪCH AND ICHTHYOPHAGI
}

\author{
By Brian Spooner
}

An enquiry into the present condition of the Persian province of Balūchistān, its antecedents and potentialities.

\section{Introductory}

This article has been written with the aim of providing a general account of available information relevant to the province and people today, not only because no such general introduction to the subject exists, but in order to provide a context for further work of a more specialized nature.

The main sources of written information concerning one or more aspects of the province or the people may be summarized as follows:

(I) Mediaeval Muslim travellers and geographers;

(2) Indian Army officers' travelogues and reports;

(3) Two books in Persian-'Amaliyāt-i Qushūn dar Balüchistān and Sarguzasht-i Balüchistān by General Amānu'llāh Jahānbānī;

(4) The Italconsult Reports. ${ }^{1}$

The general tenor of any mentions of the Balūch in mediaeval writers is that they were "professional way-layers, herdsmen, intrepid and bloodthirsty". ${ }^{2}$ This was the general reputation of the Balüch, and the $K \bar{u} c h$ with whom they are linked in Ferdowsi, and besides the occasional mention of them in the mediaeval histories pinpointing various stages of their progress from the North-west to the South-east of the Persian Plateau, 3 it is practically all the world knew or knows of them and their origins and entrance into the province which now carries their name.

In the twentieth century, according to General Jahānbānī, the inhabitants of Balūchistān are "still living in the age of barbarism, and in these long centuries have not taken a single step on the road of progress and civilization ".4 Such was the impression made on the ancients by the aboriginal Ichthyophagi!

The province has always presented itself as something of a mystery to those unlucky enough to be obliged to penetrate its protective outer ring of deserts, or to deal with it politically. The present population would appear to be a hopeless racial mixture, but the two names which have survived to form the basis of our prejudice when we look at the province and its population today are Ferdowsi's Küch u Balüch and the Ichthyophagi of the Greeks-the one to be feared, a kind of noble highwayman raiding from one end of the central desert of the Persian plateau to the other; the other only to be despised, and so referred to as eaters of inferior food. The Indian Army travelogues and reports combine a wealth of miscellaneous but generally useful and detailed information on the province coloured by one or other of these basic attitudes towards the people.

As time has passed Ferdowsi's picture of:

"An army of warriors of the Kūch and Balūch,

Scheming war like the fighting-ram,

"No one in the world has seen (them turn) their backs,

No one has seen (as much as) one of their fingers unarmed ",

has dimmed and given way to the earlier scornful picture of the Ichthyophagi, a typical modern

I For more extensive bibliography see Italconsult Reports, Rome, July 1959 .

2 Hudüd al-'Alam, trans. Minorsky, G.M.S., 1937, p. 124 .

3 It is now generally accepted that the Balüch entered history- in so far as they can be said to have entered it at all-on the south-western shores of the Caspian. Cf. E.I.

4 'Amaliyāt-i Qushūn, p. 85. 
Persian reaction to the subject being: "Balüch-hā? malakhs mikhwurand!" "The Balūch? They eat insects!"

In I928, in keeping with Rizā Shāh's policies, Balūchistān was once and for all brought within the orbit of the central government. In 1957 as the general rate of development in Persia gathered momentum, the government finally undertook to do something fundamental and expensive about this province which had become an embarrassing economic, political and sociological backwater.

"As a result of the contacts which the Iranian Government had in 1957 with an Italian Economic Mission, Italconsult was requested to study and submit a plan for the socio-economic development of the south-eastern region of Iran ... .

"The scope and terms of the assignment were agreed upon during a visit of Italconsult's experts to Iran in February 1958. It was then decided that, also in view of the substantial lack of reliable information, ${ }^{6}$ a preliminary reconnaissance of the region should be undertaken by missions of socioeconomic, agricultural and mining experts. These preliminary reconnaissances were completed during the period from April 1958 to March 1959 ...

"Even while preliminary researches were still being carried on, the first part of the operational program - which did not include only specific surveys and investigations, but also the execution of projects warranted by the knowledge secured-was started."'

The main result of this agreement now forms a not inconsiderable library of detailed technical information on the agriculture, hydrology, geology, certain aspects of the sociology, etc., of a region in south-eastern Iran of which the province of Balūchistān forms the heart. Although political pressure from Tehran for quick tangible results somewhat spoilt the original grand plan, and the sociological side in particular faded away, nevertheless the work which was done will undoubtedly constitute a major contribution to the success of any future development programmes for the area. The Italconsult publications are not designed for the purposes of scholars in the "Arts" disciplines, whereas it is, of course, these scholars whom the writer has in mind in the present article. The "Arts" in so far as they turn their attention to the present day are interested in the intellectual and cultural condition and development of a people, or society, and the findings of other disciplines are invaluable in so far as they bear on problems arising from this type of study.

One other work deserves mention: in Between Oxus and Jumna, published only two years ago, Arnold J. Toynbee pays a tribute to the population of Balūchistan which makes refreshing reading. Toynbee is talking about the whole of Balūchistān, and particularly that part which now forms the western province of Western Pakistan. Nevertheless, his words are equally applicable to the Persian province. He writes: ${ }^{8}$

"The austerity of the landscape has a beauty that is all its own. The fantastically jagged sky-line delights the eye, but it provides no sustenance for the body. Yet man does wring a living out of this inhospitable land; he has, in fact, been making it support him since before the dawn of civilization. To a stranger's eye the landscape of Central Balūchistān looks irredeemably barren. Yet, for thousands of years, this country has been producing fine wheat and still finer wool.

" How the flocks keep alive is a mystery. You see them obediently following the shepherd as he strides ahead of them across the country. They have to traverse their pastures rapidly because the pasturage is so thin; and they must have to travel many miles more to find a drink. The flocks throng around every pool of rainwater. They are under constant attack by hunger and thirst . . . It is also a mystery that Central Balūchistān should contrive to be a granary as well as a wool-farm. The rare irrigation-water is too precious to be wasted on so unprofitable a crop as wheat; so nearly all the wheat-

\footnotetext{
5 The author is aware that in literary Persian the word malakh means " locust". However, in Balūchistān and in most, if not all, of eastern Persia, there are, in peasant parlance, three types of malakh, namely, malakh-i darya' $\bar{i}$, malakh-i hava'i, and malakh-i ma'müli, meaning, respectively, "shrimps", "locusts" and "flying insects" in general. It may be said that, in these regions, the word malakh, unless the context is specifically regarding locusts, means " insects" or at least " flying insects" in general. Moreover, it is noteworthy that Persian peasants
}

regard locusts as a delicacy, so it is unlikely that they would ridicule the Balüch for eating them.

6 Author's italics.

7 Italconsult, op. cit., vol. I, p. vii.

${ }^{8}$ The author is most grateful to Professor Toynbee and the Oxford University Press for giving him permission to quote the passages that follow from Between Oxus and Fumna. These passages are on pages $I 74$ and $I 75$ of that book. 
fields in Central Balūchistān depend for their water on catching a few drops of precarious rain. Wherever the terrain allows, an earth-built dam waits patiently for a casual shower. Perhaps, every other year or so, this 'band' will collect enough rainwater above it to warrant the peasant in sowing the plot in the hope of catching a crop. As I travelled through this thirsty land during the fourth week in June, I was amazed to see how many of these rain-fed fields were golden with ears ripe for harvest. The crop is thin; the harvesters gather it, stalk by stalk, into tiny bundles. Yet the aggregate amount of grain harvested must be great, and this starveling wheat is as fine in quality as the starveling wool. I have never eaten more tasty or more nourishing bread.

"The present-day inhabitants of Balüchistān are heroes on a pathetically puny scale, but their prehistoric predecessors were giants. The dams that are going concerns today are modest earthworks, but the gabar bands (' heathen dams') of the pre-historic age are massive piles of well-built masonry. The present-day economy, heroic though it is, is dwarfed by the relics of this higher economy dating from a distant past. What is impressive is the amount of labour that man has been willing to expend in the hope of reaping so small a reward. Where there is some mighty river to be tapped for volumes of water that will irrigate millions of acres, it is not surprising that human beings should be willing to undertake laborious and costly irrigation works. But a gabar band on the chance of a catch-crop: that is heroism indeed."

But this is also a net criticism, for the Balūch have not preserved the capital inherited from an earlier population.

The above sources were prepared for various purposes and from varying points of view. It is the present writer's aim to provide a general introduction to the whole study of the area, with sufficient detail to delineate the special problems it must pose for any scholar who approaches it, whatever his particular discipline. For the condition of the Persian province of Balūchistān poses several universal questions for which there are no ready-made answers: what are the criteria for calling a society backward? Should we measure simply by economic, industrial, or even agricultural and pastoral yardsticks? Does culture come into it? Adherence to a world religion? Discussion of these questions could be the starting point for the formation of a universal political philosophy towards such areas.

\section{Geography}

The accompanying map (which also shows the routes which are the limits of the writer's first-hand information and were travelled in the winter of 1962 and the spring and early summer of 1963 ) is an attempt to show at a glance the peculiar natural advantages and disadvantages of the area. It is surrounded on the north and west by stretches of one of the most notorious deserts of the world. The southern coastline is uniformly inhospitable with the one exception of the natural harbour of the Gulf of Chāhbahār. To the east the border with Pakistan attempts to cut it off from what is in fact the natural continuation of a homogeneous geographical region. Altitudes range from sea-level along the coastal plain to over I3,000 feet at the summit of the semi-active volcano Küh-i Taftän, and the climate varies accordingly. The whole area falls into natural subdivisions:

(a) The coastal plain, including Dashtiārī, flat, and with good soil, but scanty and undependable water supply.

(b) The Makrān range, which crosses the province from east to west, extremely difficult to traverse, consisting almost entirely of jagged peaks and deep ravines, and seldom a piece of ground large or level enough to pitch a group of tents, or safe enough from occasional lightning floods.

(c) The Jāz Mūriān depression containing the fertile well-watered plains of İrānshahr, Bampūr and Dalgān, altitude approximately I,500 feet, but with temperatures soaring into the fifties (Centigrade) in the summer.

(d) The Sarāvān area, up on the general Iranian Plateau level, consisting of small plains varying in altitude from under three to over four thousand feet, and separated by ranges whose highest peaks exceed nine thousand feet. The two main ranges are Kūh-i Birg and Kūh-i Safĩd. It is these ranges and the Makrān range that contain the flocks of people who maintain the old quasi-nomadic life of earlier times, as isolated from the mainstream of the life of Iran as it is possible to be. In colloquial 


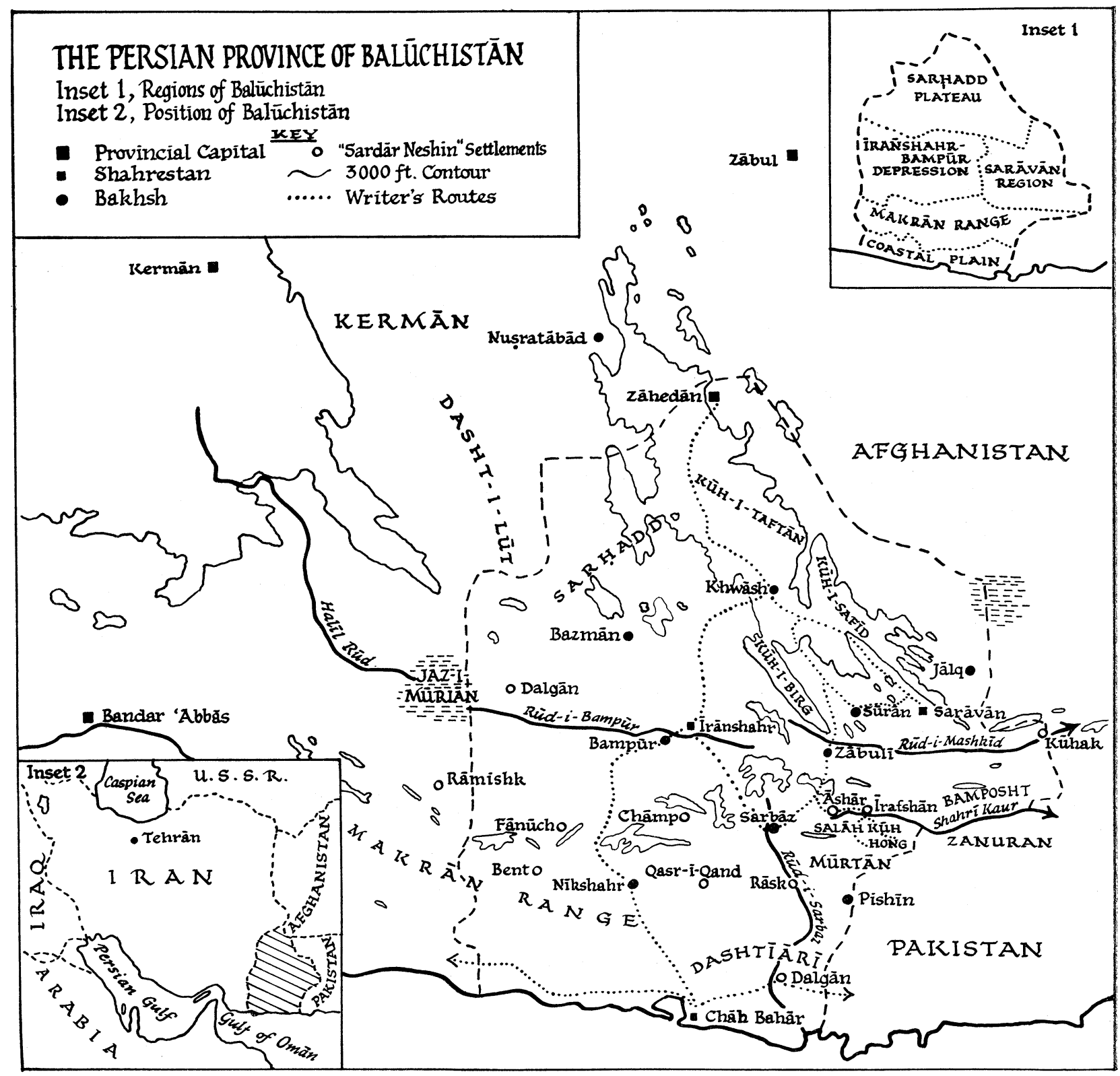

Fig. I. 
speech it is these people that the Balüch refer to as Balüch. They live a life completely unprotected from the extremes of the climate, and tempered by none of the comforts and aids of civilization that cannot be simulated by a plaited or twisted palm leaf. Even in the most advanced centres of settlement of Balūchistān there is a lingering respect for the courage, industry and mores of these people, and a feeling that among them only is preserved the nobility of spirit which was once the possession of the whole people. It is in these people if anywhere that the spirit of Ferdowsi's Küch $u$ Balüch is not yet quite dead.

The rivers of the Sarāvān region flow eastwards into Pakistan, and the plains and mountain ranges gradually lose height towards the border. In fact, "geographically speaking, the (whole) region of Balūchistān seems much better connected with the two bordering nations, Afghanistan and Pakistan, as evidenced by the fact that the road network is better suited to serve eastbound rather than westbound traffic . . . Current trading, rather modest in volume, is mostly eastbound, in both its legal and illegal forms ", 9 and outside the main centres, more people appear to speak Urdu than Persian.

(e) One quite large area remains: the sarhadd or border country. It is higher and cooler than the rest of the region and contains the highest mountain of the province, the Küh-i Taftān. It is an area of immense plains broken by isolated mountains. Cultivation is scanty. If the spring rains come the plains provide good forage for large flocks of sheep and herds of camels. When the rains do not come the barren plains merge with the Dasht-i Lüt to the north and west. Even in a relatively good year such as this year has been, the traveller may cross enormous distances and see no movement, except perhaps a lonely camel wandering from tuft to tuft in a stone-strewn semi-desert.

The main centres are marked on the map. The main administrative centres: Zāhedān, Khẉāsh, Sarāvān, Irānshahr, Chāhbahār, can now be called small towns. But this is only a very new development. Formerly, there were simply centres of influence: the seat of the sardär, which was often a fort or castle on a hill, artificial or natural, surrounded by the mud houses or tents of his immediate attendants and ghulams. Any cultivated plots, palm groves or fruit gardens might or might not adjoin. Bazaars had no place in the settlement. Any trade that existed was by no means a conspicuous activity, and was normally conducted by aliens rather than the Balūch themselves. The main factor in the selection of the site would have been its suitability for a fort in the first instance. Those places marked on the map as sardär neshin, and not administrative centres, continue to be this type of settlement. Even Sarbāz (which is now the centre of an important bakhsh), mainly no doubt because of its situation strung out along the sides of an important perennial river in the Makrān range, defies any attempt to give it shahriyat - the appearance of a town, and still boasts nothing approaching a bazaar.

Communications are similarly primitive. For owing to the relative unimportance of trade in the life of the province and lack of attention from the central government the importance of roads is still perhaps not fully realized. There is one main road from north to south, reasonable to Khẉāsh (I 20 miles); possible to Irānshahr (I 20 miles), and jeepable for the remaining 200 miles to the coast. The road from Khwāsh to Sarāvān (I Io miles) is also reasonable. Anywhere else is accessible only by jeep-type vehicles, and the coastal plain west of Chāhbahār and the areas of Irafshān and Bampusht are still completely roadless. The three main mountain ranges mentioned above are in many cases impassable even for donkey traffic. Owing to the nature of the terrain routes are in most cases obliged to follow water courses. Some of the main rivers-Rūd-i Sarbāz, Rūd-i Bampūr, Rūd-i Māshkīdhave water flowing at least in some stretches of their beds throughout the year. All water courses are subject at any time of the year to lightning floods of such force and unexpectedness that lorries caught unawares under a blue sky have been carried miles down stream and broken up against the rocks.

It is these lightning floods, when they occur, that keep the pasturage for the flocks in the mountains green throughout the year. Agriculture depends, however, on seasonal rains. Wheat is almost entirely rain-watered, and the harvest starts in early May, continuing to the beginning of July according to altitude. Two good downpours, provided they come in early spring, ensure a good crop.

9 Italconsult Preliminary Report, vol. I, p. 7, Rome, July 1959. 
This year, after four years of nearly complete drought in most parts of the province, the rain came late, and in the small village in which the writer was staying between Āshār and Irafshān the crop was so negligible that it sufficed for six weeks' consumption only.

One other form of precipitation also occurs in the summer, but apparently only in the mountains south of Irafshān. This is a type of Scotch mist, known locally as "nōd", which may come in over the mountains from the east towards the end of the night and last until noon. In the limited region where this occurs it is a useful factor in keeping down the summer temperatures and revivifying the vegetation.

The most important crop, other than wheat, is the date crop. Besides providing perhaps the staple item of the ordinary people's diet, the yearly surplus traditionally forms one of the few exports from Balūchistān. Hämin - the time of the date harvest-begins at the end of June in the hotter parts of the province and continues into the early autumn in the higher and cooler parts. Hämin is one of the important occasions of the year, when the people come in from the mountains and the surrounding country to gather and eat and store away the dates.

Other important crops are rice and millet of various types which together make best use of the available irrigation water through the summer and autumn. At times, mostly during the winter, when agricultural work slackens off, there is a tendency for movement in the opposite direction to that seen at the time of Hämin: into the mountains to the flocks.

Agricultural settlements may be divided into two main types: those making use of river water for irrigation, and those using qanäts. Except for parts of the sarhadd where immigrant Persians from the Kermān and Yazd areas have long had a hand in agricultural activity, qanäts in Balūchistān are rather elementary; in fact some of the so-called qanäts are simply channels led off under the banks from perennial streams. I was unable to find a Balūch muqanni, and it would appear that the Balūch themselves have no knowledge or experience in the art of exploiting ground water by means of qanäts. So who built the few respectable qanäts that do exist in Balūchistān south of the sarhadd? Until recently, so it was said, the Balūch themselves had no idea, and even gave the credit to divs. As we shall see later, only now, owing to the changing pattern of social security and a certain amount of planned development, is agriculture in Balūchistān (since it has been called by that name) becoming a necessary and therefore respectable occupation.

\section{History}

There is not sufficient space here to fit together all the miscellaneous historical information available on Balūchistān. However, certain factors in the comparatively recent history of the province are necessary to a proper understanding of the present situation.

In the tenth and eleventh centuries A.D. we read in Ișțakhrī and Mas' ${ }^{6} \bar{d} \mathbf{i}$ of the Balūch first in the mountains of Kermān, and later in Sīstān together with the Kūch. Ferdowsi mentions the Balūch as part of Kai Khusrau's army. Elsewhere he talks of an alliance between them and the tribes of Gīlān and war between them and Nūshïrvān. The general opinion of scholars is that the Balūch came from the shores of the Caspian, first to Kermān and Sistān, and then to the Makrān and the other districts of Balūchistān, and that this migration started in the time of Nüshïrvān. In the fourth century they were making a nuisance of themselves raiding from the Kermān mountains and Sistān as far as north Khorāsān. Both 'Azudu'd-Dauleh Dailamī and Mas'ūd of Ghazneh were forced to deal with them. The former killed quite a number of them, and the latter inflicted a severe defeat on them near Khabiṣ. The arrival of the Seljūqs in Kermān was probably the main factor that drove them into Balūchistān proper, and in A.D. I 252 we hear of them as far east as Sind. ${ }^{10}$

So much for their arrival in the province. During the last two centuries, after the death of Nădir Shāh in 1747 , the province was for a time under the Durrāni rulers of Afghanistan. Then followed a period of anarchy, after which eastern Balūchistān (now in Pakistan) finally acknowledged the suzerainty of Nāṣir Khān, whose power was felt as far west as Bampūr. But his successors were degenerate and Persian Balūchistān was independent when Pottinger crossed it in I8ıo. In I839 an intelligent traveller by the name of Hājji 'Abdu'n-Nabī reported that Muhammad Shāh of Sỉb

so 'Amaliyät-i Qushün p. 26-historical chapter written by S. H. Taqizādeh. 
was the most powerful chief in the province. During the reign of Mohammad Shāh Qājār manœuvres were undertaken in Balūchistān by the Persian government and the Bampūr fort was taken. From that time Bampūr remained in Persian hands, and gradually other centres were brought under government control. In the eighteen fifties the son of a baker from Bam, Ibrāhim Khān, was appointed to the governorship of Bam, Narmāshìr and Bampūr. His qualifications and efficiency in centralizing the influence of the central government in Balūchistān, and the fact that he brought the inaccessible district of Sarbāz under his control were a great service to the Persian government. He died in 1884 , after thirty years in office. His son died only a few months later, and Zainu'l'Ābidin, his son-in-law, became governor, but in 1887 he was succeeded by Abu'l-Fath Khān, a Turk. Abu'l-Fatḥ Khān was, however, soon dismissed, and Zainu'l-'Ābidin Khān reappointed. In the reign of Nāṣiru'd-Dīn Shāh, in the winters, the governors of Kermān began to take their armies into Balūchistān to collect taxes. In I89I, after an absence of two years, the governor of Kermān visited the province, making solemn promises that he would imprison nobody; but these were broken, and the Balūch chiefs were seized, many of them being in prison when Sykes first visited the province a year later. About this time the common Balūch term for a Persian became Gajar (Qajjär), pronounced, as Curzon well remarks, very much like the English word "cudgel "."

On the assassination of Nāșiru'd-Din Shāh anarchy returned and the province became independent again until in 1928 Rizāa Shāh ordered its reduction and inclusion once and for all under the administrative system of the central government of Persia. The paramount chief or sardär at this time was Dūst Muḥammad Khān Bārānzā'ì. Dūst Muḥammad Khān had allied himself to most of the other influential families, and collected a tax, leaving some of it to the local sardārs for the upkeep of irregulars for whenever he required them. According to General A. Jahānbāni ${ }^{12}{ }^{12}$ who commanded the operation, he wanted to be independent from the central government, but was willing to pay some form of nominal tribute. His power was strongest in the Bampūr and Sarāvān regions, but only the sarhadd region remained at all independent of him. According to Jahānbānī's own account, on his entry into Khwāsh the sardārs of the sarhadd region attached themselves to the government forces almost without hesitation. ${ }^{13}$ The Persian forces were comparatively well equipped with the weapons of the day, and Dūst Muhammad's only real hope of survival lay in the peculiar climate and topography of his country. The Balūch generally did not believe it possible that their forts could be taken. They had seen Persian armies come before, but they had always gone away without achieving anything-beaten by the heat of the summer if they outstayed the winter. ${ }^{\mathrm{I}}$ But this time, before the end of the winter it was all over. Dūst Muhammad was left no choice but to surrender and accept safe conduct to Tehran. ${ }^{\mathrm{IS}}$

With the removal of Dūst Muhammad Khān the last shadow of Ferdowsi's Küch u Balūch disappeared from Balūchistān. Three times since the ghost has appeared: in the abortive revolt of Jum'eh Khān Ismā'îlzā'ĩ in the sarhadd in I93I, a revolt in Kūhak subdued by General Alburz, and the Dādshāh episode, but it would now appear to have been laid for good. There remains the shadow of the Ichthyophagi, which in the conspicuous loss of self-confidence among the Balūch themselves and the derogatory and uninformed attitude towards Balūchistān which is widespread not only in the rest of the country but also among the Persian government officials who work there, remains the main obstacle to the development and integration of the province into the political and economic life of the rest of the country.

\section{Social Framework}

The word Balūch used to signify a particular Iranian tribe. All it can now be said to signify is a man whose native tongue is Balūchì. The travellers in the last century notice that many of the

\footnotetext{
12 Persia and the Persian Question, Hon. George N. Curzon, 1892, vol. II, p. 259.

12 Op. cit., p. $3^{8 .}$

13 Op. cit., p. 45.

14 Op. cit., p. 70.

15 Rizā Shāh pardoned him and he lived in Tehran quite freely though under surveillance for a year, after which in an
}

apparently rather impractical attempt to escape back to Balūchistān he killed his guard and was hanged for common murder. For the information in this historical outline $\mathrm{I}$ am indebted to Sykes: Ten Thousand Miles in Persia, London, 1902, and Jahānbāni's op. cit., including the chapter by S. H. Taqizādeh. 
sardärs, and therefore the common people, claimed Arab ancestry. Sykes realizes that the sardärs are probably of an alien origin, and that the remnant of the Iranian tribe are to be found among the peasantry. He enumerates the following details which he collected about the chief families:

"The Gichki are the descendants of a Rajput family which settled in Baluchistan as late as the I 7 th century. The Bolidi ${ }^{16}$ hail from Muscat, the Malik are descendants of the Saffar dynasty, while the Noshirwani were dispossessed by Shah 'Abbas, who drove them from the neighbourhood of Isfahan to make room for Armenian settlers. The Bezanju are a branch of the Brahui . . . the Hots are a branch of the turbulent Rinds, who resemble Arabs more closely than any other Baluchis, and are proud of the fact; while the Akazai, Sadozai and Askani Rinds, the Kowda and Jadgal, the Kalmatta and the Gurgij, claim to be descended from Aleppo exiles, but Jadgal merely signifies Jat speech. ${ }^{17}$ The Shahzada tribe claims descent from the princes of Kandahar, and the Ra'is are, I understand, descended from the famous or infamous Ghazz. The Meds are aboriginal pirates, ${ }^{18}$ the Darzads are serfs. The Luris represent the gypsies, and the Wardilis immigrated from Sind."Ig

The Shahbakhsh (formerly Ismā'īlzā'ī) claim to be descended from a certain Ismā'îl Khān who fled to Balūchistān from Fārs eight generations ago, was protected by the paramount chief of the time, stayed and finally founded a tribe. And this is the most likely explanation of how most of the present " tribes" of Balūchistān came into being. A new man appears, a man whom the ordinary people see, or want to see, roughly equal in standing with the existing sardärs. Two of the ways in which this might happen are (a) a member of an existing chiefly family breaks away from the patriarchal authority; or (b) a noble alien appears and is protected and favoured by one of the sardärs. The kernel of the new "tribe" is formed by the new man's immediate family and retinue when he has one. The rank and file is formed by a change of loyalty on the part of a section of the peasantry. Although such a change may no doubt in certain circumstances take place over night, more normally it would take the form of a very gradual, almost imperceptible movement such that the new man himself would not be conscious of having founded a new "tribe" or focus of loyalties, and it may be left to the time of his heir for the fact to be generally recognized and the name attached. Such gradual shifts of loyalty can be observed in progress today.

The most important " tribes" now are the following: Bārakzā'ī, ${ }^{20}$ Mīr Murādzā'ī, Buzurgzādeh, Bulīdeh-ī, ${ }^{21}$ Shīānī, Mubārakī, Rigin, Shahbakhsh. These are the big families, and all other tribes or families and their following pay what amounts to allegiance to one or other of them. There is a considerable proliferation of tribal names, and some of the politically minor tribes are among the largest in number, but can claim no members of the sardār rank. Similarly, the sardār relies for his position on a large and undefined confederacy of which his own tribe may constitute only a small proportion. The Shahbakhsh, centred to the west of Zāhedān, in the outer sarhadd, are little involved in the general inter-tribal politics. The Rigi's influence covers the remainder of the sarhadd and penetrates into the Irānshahr-Bampūr district. The first five mentioned above form a confederacy whose influence covers the whole of the remainder of the province with the exception of a little island around Chāmp which is controlled by the Mubārakī. And at the end of May Ig63 the Mubārakī ostensibly came to terms and joined the confederacy. ${ }^{22}$

The internal politics of this " confederacy" depend on personality, descent and marriage alliances. Within the framework of tradition the people choose their own sardār. At the present time, which, to use their own terms, we shall call the Post-Balūch period, ${ }^{23}$ this is done by referring their disputes to him and accepting his judgement, and supporting him in his friendships and enmities with other sardärs. In making their choice they are influenced by the three factors defined above. A few examples may help to illustrate this:

16 The form now used as Bulideh-i.

${ }_{7} 7 \mathrm{Jadgal}$ is in fact the plural of Jat.

${ }^{18}$ It has been suggested that these are the aboriginal Ichthyophagi.

19 Sykes: Ten Thousand Miles in Persia, London, 1902, p. 97. Another obvious example is the Kurds around Kūh-i Taftān and in the Zābuli plain, who have retained the surname of their origin though otherwise entirely Baluchized.
20 Also called Bārānzā'î.

${ }^{2 r}$ Also called Sardārzā'ì.

${ }^{22}$ At the present time the main cause of friction between these families lies in disputes over ownership of various properties in the İrānshahr-Bampūr plain.

23 i.e. since the demise of Dūst Muhammad Khān. The period before that is referred to as the Balūch period (Daureh-i Balüch). 


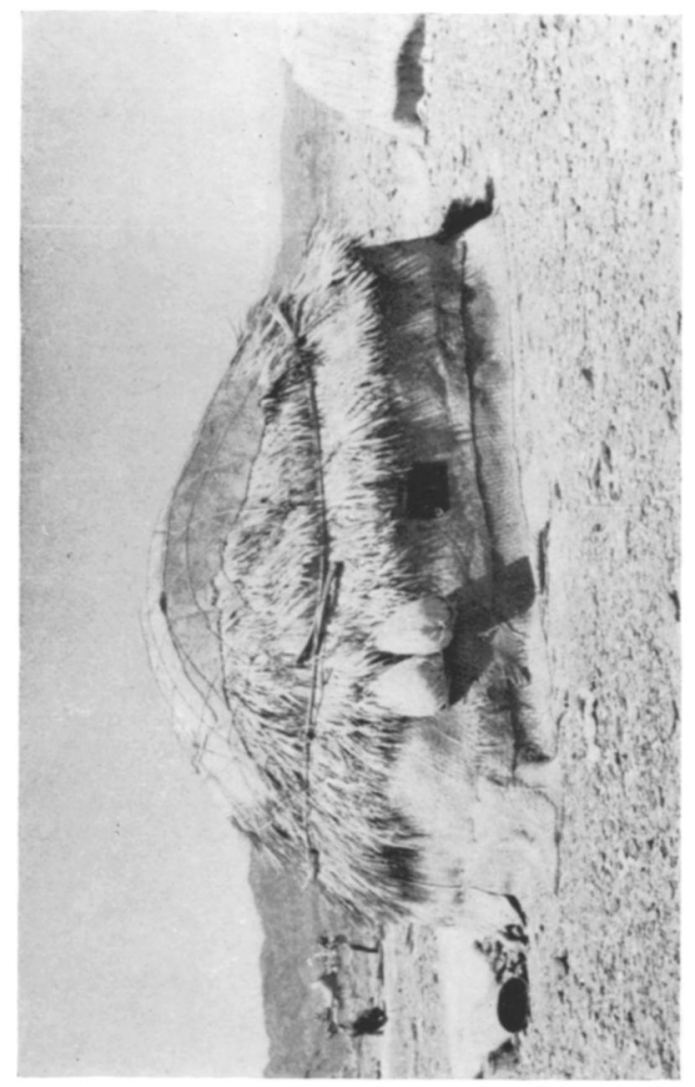

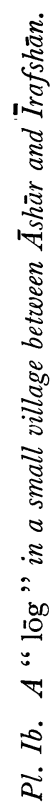
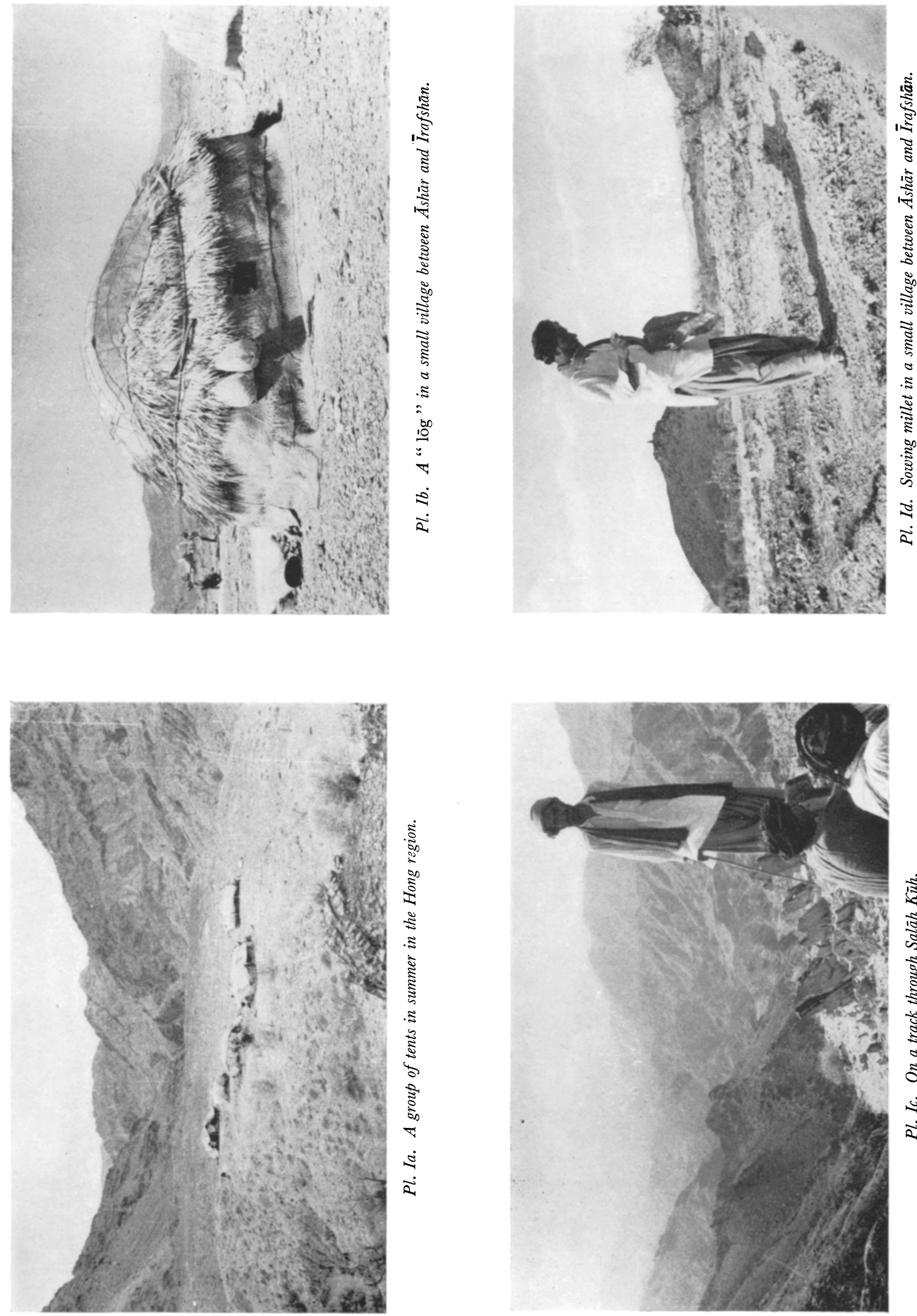

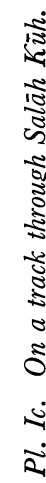



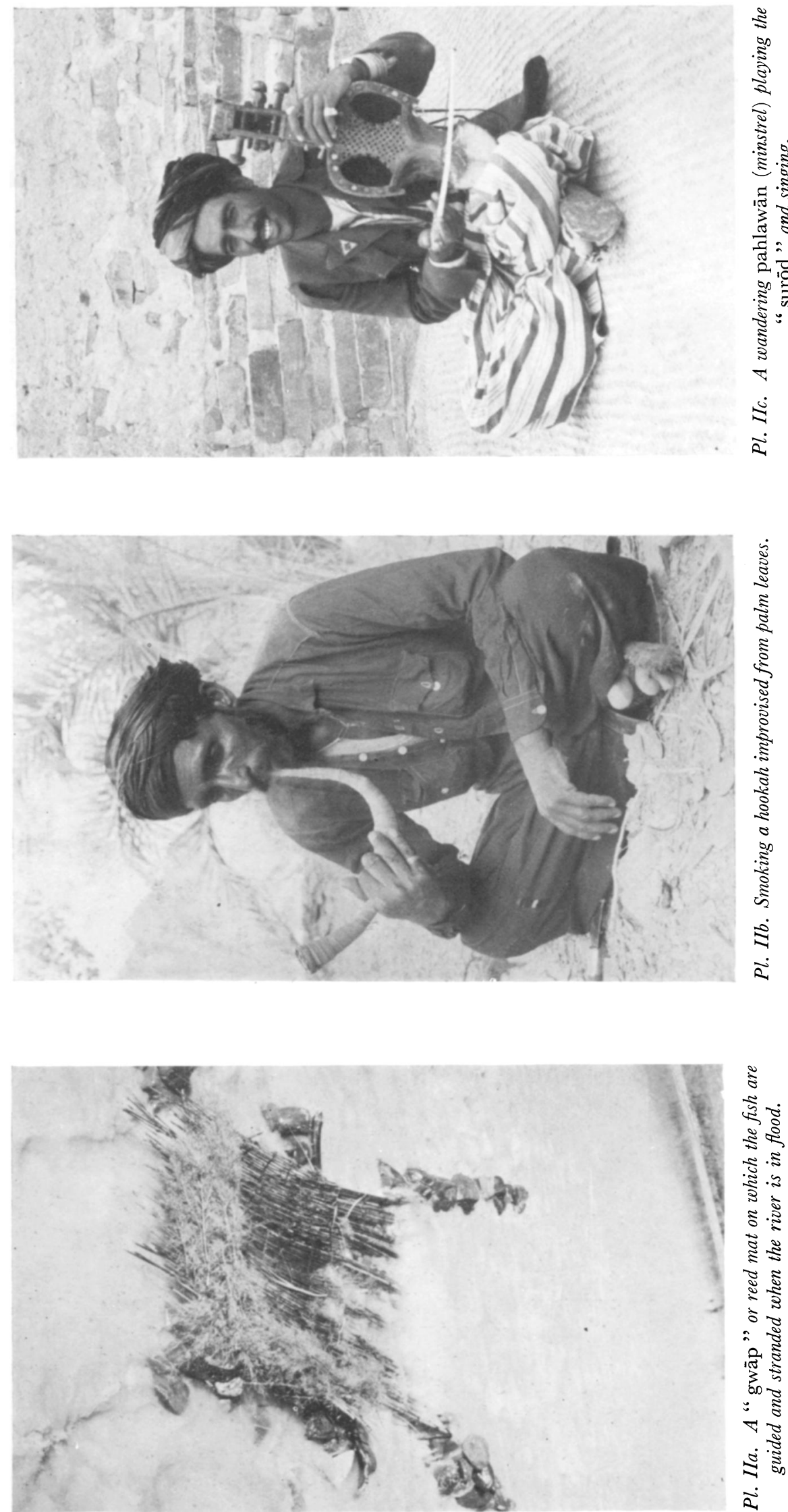

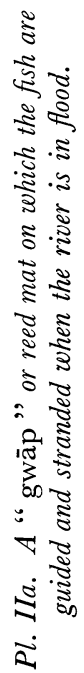

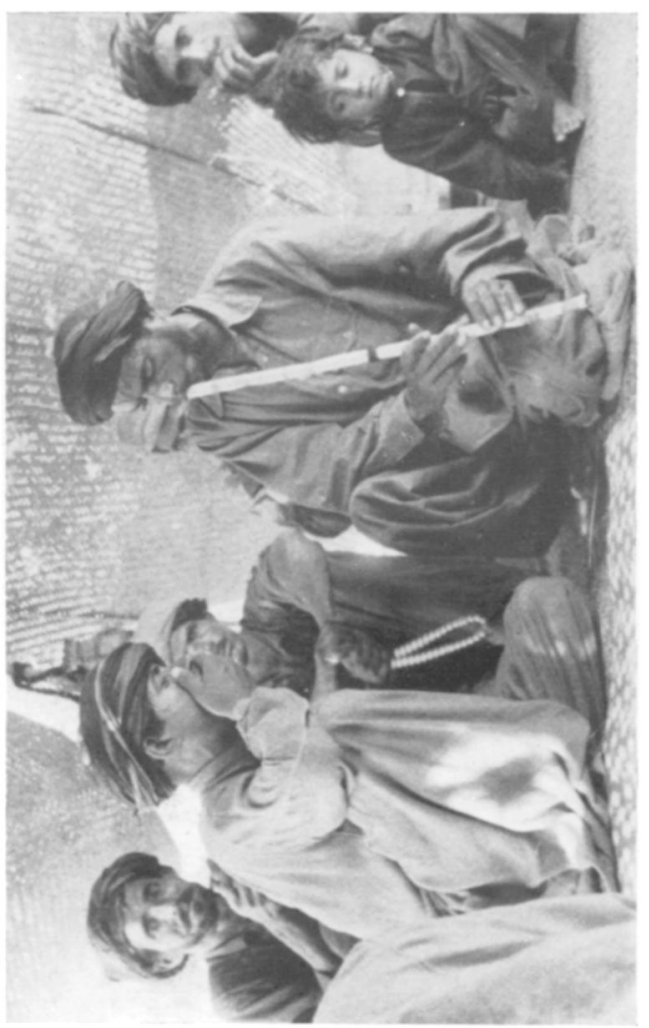


The "confederacy" would seem to be to a large extent the outcome of the statesmanship, or at least political acumen, of Dūst Muhammad Khān. He left five sons. The eldest, who according to all accounts was unusually suited for his position and immensely respected by all who came into contact with him, died in rather mysterious circumstances only a few years ago. The next eldest has been by-passed by the people who have almost unanimously attached themselves to the third son who is considerably younger. And the difference between the two, except for personality where the younger admittedly gains, is that the mother of the younger was Bārakzā'ì, whereas the mother of the elder was Mir Murādzā'i ${ }^{24}$ This is the more interesting when we remember that the Balūch have an almost excessive respect for age, and especially for the father and elder brother relationships.

The next most important man in the confederacy is the head of the Bulideh-i family. He is easily the most travelled and active man of the six families and the most acquainted with Persia outside Balūchistān. He may in fact be more popular than the son of Dūst Muhammad, but because of the lineage of the latter and the recent history of his family he would give way to him in any gathering.

While I was living in Sarāvān a visit of the Governor-General to the heart of the province, Irānshahr, required the presence of the more prominent sardārs. The son of Dūst Muhammad was summoned from Sarāvān, but instead of simply answering the summons and proceeding to Irānshahr on his own or with one or two of his close associates, he gathered on his way some dozen of the less prominent sardärs of the district, who on their arrival in Irānshahr joined with others of the confederacy, eventually presenting a formidable front on the issues which were to be discussed. On occasions such as these in particular there seems to be a ready understanding of the fact that the force of a man's word or opinion lies in the number and quality of his allies and supporters, and the more conspicuous these are the better.

The main centres of tribal influence, that is, the seats of the more prominent sardars, are marked on the map. In general, the further they are from administrative centres and roads, as might be expected, the less influenced they are by mid-twentieth-century Persia. Such a place is Irafshān and the area dependent upon it: Salāh Kūh, Hong, Mūrtān.

The sardār of this area, a Bārakzā'ī, estimates the population at between five and six thousand families. Irafshān itself consists of some eight groups of mud huts strung along both sides of the Shahri Kaur river. One of these "villages" houses the sardarr, one of his brothers, and their immediate dependants and ghuläms. The whole area is cut off from the rest of the province by very difficult country and parts of Salāh Kūh itself are impassable even for donkey traffic. For the conduct of his affairs in Hong and Mūrtān which lie the other side of the Salāh Küh range, the sardār conducts his affairs through a representative known as a päkär. In the remainder of the territory there is in theory no intermediary, but owing to bad health he has been unable in recent years to travel as freely in such difficult country, and relies mainly on a younger brother (of an inferior mother) to maintain contact. In this and other similar areas there is still no government influence except through the medium of the sardār and his representatives.

The sardār class as a whole normally have property interests in several quite different parts of the province and travel quite frequently and regularly from one to the other. They normally keep their wives and family in the district where they have the most property, but they may keep one wife in another of the districts in which they have an interest. Thus by continually travelling from one district to another they keep very close contact not only with one another, but also with the peasantry which is connected with their interests. Wherever he goes the sardär is accessible to the peasants, and he is most generally found surrounded by a group of them and talking with them on quite equal terms, while tea and hookahs are passed round. Actual ownership of land and water rights, even among the sardärs, is on a relatively small scale compared with what prevailed among the landowning class in the rest of Persia until recently. None of the Balūch landowners are affected by the present Laand Reform law. Similarly, even the lowliest Balūch peasant usually has some form of property, however little. The general pattern of ownership therefore throughout the province is khwurdeh-mälek-with the exception of the ghuläms.

24 In fact, a sister of Muhammad Shāh, the Mï Murādzā'i Sardār. 
The position of the ghuläm in Balūch society in many ways emphasizes the main differences between this province and the rest of Persia. He is conspicuously and consciously of a different race from the peasantry, and his origins, though obscure, should probably be sought in an historical study of the Arabian slave trade. For the ghuläm has been a slave, and in ordinary terms, though in theory now free, still generally is either slave or serf. The typical ghulam is very dark, with fuzzy hair and scant beard. In purely Balūch environment he has no rights. He may, however, be the favoured retainer of the sardär and his most trusted servant, and so lead a more comfortable life than many of the peasants. In Balūch society every man knows his place, and in general never fails to show respect where he knows it is due. In a large gathering the ghulam will usually be found at the back in the shadows, though he may take full part in the conversation in such a way that it would be difficult to mark any social difference between him and the others gathered. And in a small gathering all may sit round in one circle.

One of the most conspicuous things in the life of the province today is a disastrous lack of selfconfidence and initiative. This is no doubt due to a large extent to the rather ignominious defeat thirty-five years ago, for that campaign was in fact a fight to the death between central authority and all that the word Balūch had traditionally stood for. And the latter lost. But this defeat might not be expected to have had the same effect on the ghuläm as on the Balūch. It is perhaps a measure of how unready the whole population was for social change that the ghuläm has taken so little advantage of this. The theoretical freedom it gave him, at least until the integration of the province into the life of the rest of the country becomes more meaningful, amounts only to the freedom to choose to leave his neighbourhood, which in an area as economically backward as this would in most cases result in him becoming a beggar, or if he is lucky he may make good in Karachi or one of the Arab shaikhdoms. However, there are now ghulams who solely by their own efforts and industry have become respected and useful members of the community-though the Balūch never forgets that a ghuläm is a ghuläm. One such, a native of Irafshān, whose father was killed at Dizak ${ }^{25}$ in the service of Dūst Muhammad Khān, campaigned for the opening of, and now runs, two local schools in Irafshān and Āshär-some twenty-four miles apart, and has also acquired a certain amount of property in the Sarāvān area. Others may be found in government offices. However, even such as these who have found their way into the new order which slowly and clumsily, but nevertheless surely penetrates deeper and deeper into the life of the province, in the evenings when they return to their homes and the round of Balüch social life are still automatically ghuläms and servants.

The section of the Makrān range immediately to the south of Irafshān, known as Salāh Kūh, is one of the most difficult pieces of country in the province. According to official statistics it holds a population of 2,213. However, in view of the constant traffic backwards and forwards across the border and the complete lack of incentive for the people to obtain identity cards (it is on the issue of identity cards only that the statistics are based), it would seem probable that the potential population is a great deal more. Towards the centre of this tract of country a knot of peaks divide it into three segments draining towards Irafshān and the Shahrī Kaur river, Hong, and Mürtān respectively. The first of these districts has the closest links with the sardār family of Irafshān, while in the latter two a päkär looks after the sardär's interests. At the Hämin season the people from each district gravitate towards the respective centre. Hong itself is really only inhabited at this time. During the remainder of the year it is generally only visited during the day by those tending the palms or working the small area of agricultural land when there is enough water to allow this.

The basis of the economy of this mountainous area is, of course, sheep and goats. A small number of cattle are bred for sale. But an apparently new and growing factor in the economy of the area is the construction of small dams or silt traps ("garband") in the steep narrow ravines, behind which, when it rains, enough moisture and soil are caught to keep alive half a dozen palms, perhaps more, perhaps less. Or a heavier rain than usual may carry away the garband, soil, palms and all. This is the heroism that impressed Toynbee, ${ }^{26}$ and certainly when the amount of hard labour required,

\footnotetext{
25 Now renamed Dāvar Panāh, a few kilometres from the centre ${ }^{26} \mathrm{Op}$. cit., pp. $172-5$.
} of Sarāvān. 
the risk involved, and the minuteness of the crop which may survive are considered together, it is heroism indeed. Behind some such garbands the writer has seen a wide (though numerically very small) variety of fruit trees-from pomegranates to bananas-flourishing, and the ground under and between them utilized for melons and vegetables. In earlier accounts these garband are called gabar-band, ${ }^{27}$ and like the qanäts of the plains their origin is referred back to primaeval or supernatural forces. The industry which is presently displayed in creating new ones would appear to be a relatively recent development, post-dating the "Balūch period". What had existed previously were built before the living memory of the present population and so attributed to "heathens" (gabr). They are now being built in the smallest of ravines wherever there is enough soil to take the roots of a few palms. The reason for this new interest in " agriculture " is probably to be sought in a kind of security vacuum caused by the entrance of the central Government into Balūch affairs. These Balūch of the mountains are a kind of superlative Balūch: the men of the plains refer to them as Balūch in distinction from themselves. Never being tied to the land they could always be free for the errands and campaigns of the sardärs.

In a normal year, if such a thing can be said to happen in Balūchistān, these Balūch are by their own standards almost rich on the produce of their flocks. In a bad year they used to be able to live on the sardār. This they can no longer do. The sardärs no longer have very much use for such services, nor the means to retain them, though they retain a special affection for these Balüch of the mountains. This new exploitation of the soil in a country where neither soil nor water for irrigation exists in really exploitable quantities is a desperate attempt to find a new security.

The situation is further complicated by the Islamic law of inheritance: a flock can be divided and divided again and again ad unum because in normal circumstances it will always reproduce itself again. Not so with a small plot of land and a few palms confined by the high vertical walls of a narrow ravine. This applies equally to larger plots with a longer history. Hong is watered by a qanät of considerable potentiality. Since the ownership of the qanät is now divided among several hundred people, no system can be worked out for the necessary upkeep, repair, and extension of it which would satisfy and be fair to all the owners. And so the flow of water and the cultivation it supports gradually diminish.

Besides being an extreme example of the drawbacks of the Islamic inheritance law when applied to agriculture in poor areas, Hong is also a good example of the mental and physical separation in the area between agriculture and shepherding. No one actually lives at Hong itself. The inhabitants of the area (the mountain Balūch or Balūch in general) are divided up into groups of one to five, usually inter-related, families, each of which chooses for themselves a site for their tents. The main requirements for this site are proximity of drinking water, suitability for the flocks, and sufficient distance from any agricultural land to avoid the danger of the flocks wandering and spoiling the crops. And the site may be changed as and when conditions vary, or simply to avoid the memory of an unpleasant event such as the death of a child. For these reasons throughout the province-with the exception of much of the sarhadd where the terrain is different, and parts of the plains which are almost entirely agricultural such as the Irānshahr-Bampūr region and parts of Sarāvān-settlements, encampments (maitags), even small villages of mud huts are found on barren patches of comparatively level ground, perhaps even as much as half a day's walk from their respective plot of cultivation.

Therefore there is no such thing as a Balūch town, nor is it really correct to refer to the Balūch as nomads or even as semi-nomads. Within the region of Salāh Küh, for instance, they inhabit a particular area, of say 400 square miles, or more, or less. The fixed points in this area are the garbands, the tiny plots of cultivation and the groups of date palms. Each man is continually on the move between his maitag and the garbands in which he has an interest. The maitag itself moves irregularly according to the availability of pasturage and drinking water-which is in turn governed by the irregular pattern of precipitation. Then there is the movement away from the mountains at Hämin, reciprocated by the people settled outside the mountains in the winter at lambing time. On top of this there is the continual circulation of the sardärs and their relatives and representatives throughout

27 For discussion of the history of the gabar-bands see " The Role of Natural Forces in the Ancient Indus Valley and
Baluchistan ", by George F. Dales, Jr., in Anthropological Papers, number 62, December 1962. University of Utah. 
the province, and this has probably increased recently because of the new need to keep in touch with the administrative centres. In connection with this pattern of movement it is interesting that most place names-e.g. Sarāvān, Hong, Mūrtān, Salāh Kūh, Kazūr, Sarbāz, Bampūr, etc.-in Balūch usage are names not of fixed places but of districts of varying size, vaguely defined by topographical features. The places which have become "centres", fixed points of settlement, are settlements which grew up round the fort of a Sardär. So the "centre " of Sarbāz is really qal 'eh-i Sarbāz, and of Zābulīqal 'eh-i Zäbuli, and is so called in Balüchi. And it is in these "centres" that mud huts (kat,katän) were sometimes preferred to tents $(g e d \bar{a} m)$ or palm huts $(l \bar{o} g)$-seldom anywhere else.

In these family groups the women seldom leave the immediate area of the maitag, and on occasions when they do move outside, for example to a neighbouring family group for a wedding, they travel normally in the company of a closely related man. However, within the immediate area of the maitag there is little restriction on their movements-besides the amount of work, which consists mainly of fetching water, which must normally come from a stream often as much as a few hundred feet below the terrace on which the camp is situated; grinding corn with a hand mill and baking bread; milking the flocks in the evenings and preparing ghee; and feeding the men. Time left over from these regular tasks and not taken by washing, sewing and the bearing and rearing of a child a year is spent on the minute and colourful embroidery of the bodice and pocket of their long shifts.

The men are responsible for the animals and crops, and any small "shahr" (cultivated area) or garband they may own or have a share in. They are normally away from the maitag literally from dawn to dusk and not infrequently for some days on end. The flocks are taken off before sunrise and it is dark by the time they return. And for men not required to shepherd, a shahr as much as five or six hours' walk away will need attention; a different crop must consume the trickle of water available for irrigation. Those who return in the evening will sit and talk about the sheep they unfailingly know one from another with the aid of no distinguishing brand, or the martial glories of the daureh-i Balüch. Often there will be a guest-traveller from another maitag, on his way back from a more distant shahr, or from the sardär, with new gossip. Hospitality is limited only by the natural limits of the poverty of the region, and is the right of any traveller. The most usual evening meal is sour milk with a little ghee eaten with bread, or perhaps a heavily peppered meat soup, for occasionally a chicken is killed or there is the meat of a wild mountain goat. The addiction is a wad of local tobacco inside the cheek, or occasionally a hookah. And the relaxation is a flute and poetry.

The simplicity of the life is remarkable. Essentials imported from outside the area are confined to material for clothes, and wheat. The only surpluses within the area are ghee and wool. Household equipment consists of a few metal bowls, skins for water. The leaves of the creeping wild palm $d \bar{a} z$ (or when that is not available, the coarser "pork"), either fresh or dried, is the raw material for any other implement or item of furniture. Shoes, mats, summer tents or huts, rope, tinder, torcheswithout this ubiquitous wild palm life would be difficult indeed. To the traveller away from his tents it serves as the raw material. He seldom carries more than a water skin. When he so requires, a nearby $d \bar{a} z$ will provide a cup. If he wishes to smoke his tobacco within ten minutes he will improvise a hookah from the same $d \bar{a} z$.

He knows exactly when and where he may find water. He knows the site and condition of every wild tree, fruitful or barren, every clump of shrubs which have any medicinal or nutritional use. Should his route take him past a shahr belonging to another maitag, he has by custom the right to eat from it, ripe or unripe, whatever it may offer to satisfy his hunger. Similarly, there are no definite rights of pasture. During 1962, after some three years of drought, shepherds were penetrating with their flocks from as far north as the Māshkīd river, and there were no disputes about pasturage.

A delicacy which occasionally varies the diet is fish, which the meagre streams yield in surprising quantities. After a shower in the mountains when the river beds carry down the flood, a few hours' work produces many pounds of tiny fish. At such times each stretch of the river bed is by custom apportioned to different families. The flood purges the whole intricate network of water courses of fish, and this is in fact the only direct benefit it confers. The water itself is completely wasted, except for the little that is caught behind a garband. Otherwise the sole blessing of a flood is in its refertilization of any land over which it may pass. 
Religion

The religion of the Balūch is the Sunni form of Islam and they follow the Hanafi school. ${ }^{28}$ Their religion is of prime importance to them and it is certainly not true to say (as is often heard said) that they know nothing of their religion and are only nominally Muslims. As far as the outward appearances of Sunni orthodoxy are concerned, namāz, rüzeh, attendance of the mosque, abstention from alcoholic drinks, pork, etc., their performance is both exemplary and without fanaticism. Every village, however small, has a mosque or place set aside for prayers. The only Balūch the writer noticed omitting to keep up any of these outward signs were men who had spent a considerable period either outside the province or in non-Balūch company.

Apart from these "outward signs" and an apparently sincere effort of niyat (intention) in the performance of them, it is in general true to say that they have no further knowledge of Islam. But no religion requires the true believer to be a theologian or an historian. In fact the main centres of settlement, and particularly, of course, in the new administrative centres, there is a surprisingly good supply of Mullass, who have often studied for two or three years in Pakistan, and a fair sprinkling of Maulavis, who have studied seven or eight years in Karachi and another four or five in Delhi. There are a certain number of sayyids who are said to have come from Ișfahān probably with the Kurds sent in the time of Shāh 'Abbās, but are now Sunni. The importance and influence of the Maulavis often rivals that of the sardarrs ${ }^{29}$ and depends more on individual personality than on the religiousness of the people. Like their counterparts in other parts they stand for an unwavering fulfilment of the Law. They preach against the agricultural banks because interest is condemned by the Law. In and around the main centres in the sarhadd they have almost succeeded in closing down the occasional shrines, ${ }^{30}$ and spontaneous local music and dancing has become rare.

These Maulavis and Mulläs, however, do not monopolize the religious instincts and sentiments of the people. Here and there, often in the less accessible parts of the province, are men who may have the title of Mullä or the rank of Maulavi, or are simply called Shaikh, who withdraw from public preaching and local politics, and seek their own way independently of the "establishment" of Maulavis, and teach only those who come to them. They are often men of great personal appeal and inconspicuous piety. An outstanding example of a man of this order is Wājeh (Khwājeh) Mullā Miyā of Āshār. Throughout the areas of Sarāvān, Sarbāz and Irānshahr, the ordinary people believe in him as one closer to God than themselves, and a number of minor miracles are told of him. He is a man of great humility, and being in great demand to pray for the sick, despite his advanced age he spends a large part of the year travelling. He has travelled little outside these areas. He knows Arabic, but not Persian. He is very close to the people who seek him and works in time-honoured ways. For example, tabb mibandad-he binds a man's fever, that is, he knots a piece of thread and murmurs a verse from the Qur'ān and blows on it, and ties it round the ankle of the fevered man to break the fever. Facts such as these cannot legitimately be used to argue that the Balūch are only nominally Moslems.

There can be no doubt about their consciousness of belonging to Islam or of the difference between a Muslim and a non-Muslim. But they suffer from a complete lack of knowledge of or contact with the outside world. The few who do listen to the radio are like a man who has come in half way through the story and just does not understand what is going on. Only the häjjis, of whom several hundreds cross the Gulf every year, legally or illegally, bring back incoherent, half-digested knowledge of the cities of Arabia, and the Persian Gulf.

The Islam of the mountain Balūch is an outdoor religion, as their life is an outdoor life, and it is tempting to compare this life with that of the Beduin of Arabia to whom the Prophet taught the faith, morals and practice of Islam. As has been mentioned, certain sections of the Balūch like to think that they are descended from the Beduin, and the orthodoxy, sincerity and simplicity of their faith

\footnotetext{
${ }^{28}$ Apparently the only exception in the Persian province of Balūchistān is formed by what has now been reduced to a mere handful of families in the Sarbāz region who follow the mystical Zikri sect which has its origins on the Pakistan side of the border.
}

29 But a sardār may hire a Maulavi to settle a dispute.

30 For the general dichotomy between shrines and the official religion in Persia, see Iran, vol. I, " The Function of Religion in Persian Society", by B. J. Spooner. 
brings to mind the earlier situation. The few isolated and non-typical spots which shelter pre- or nonIslamic or heretical variations are left in the background.

\section{Conclusion}

Many major cultures and political centralizations throughout the history of civilization have grown and flourished in desert or semi-desert areas. Over the last few centuries these areas have tended to play less and less significant roles in world affairs. The fact that despite their aridity they have been among the most useful parts of the earth's surface is tantalizing to the "developers " of the present day. But efficient re-development of them often presents such formidable social problems, and is so involved and in many cases frustrated by political interests that the actual economics of the situations are simple by comparison.

Balūchistān, though it has probably never contained a large political or economic centre has always been on the borders of one or more such centres and has seldom if ever been economically independent of them. The greater part of it is desert or semi-desert. Within it, mention has been made of the gabar-bands and the more organized and larger scale exploitation of agricultural potentialities in a former age which their existence leads us to assume. However, in historical times there is no evidence to prove that the province was ever prosperous. It has always been inhabited, at times by very virile people. Before the great leap forward in communications and transport systems and the growth of the modern state, an outlawed tribe, such as the Küch or the Balūch, could win by raiding outside the province what it could not produce by agriculture and herding inside. Nevertheless, it is very doubtful whether the province as a whole has ever been rendered capable of producing over any significant period more than a subsistence level of existence for the majority of its inhabitants. The fact that the Balūch made up the difference by raiding has added to today's problems, for in addition to the general dislike and even contempt with which the ordinary Persian regards anywhere " garmsir" or off the plateau, ${ }^{3 \mathrm{x}}$ he has the peasant's memory for the suffering and losses inflicted on his ancestors by the tribes which pressed on the borders of the plateau in former centuries. On the other side the Balūch remember the first official Persian visitors to Balūchistān during the Qājār period. They were generally tax collectors, and in Balūchi the word "Qajjar " became synonymous with "Persian" and a term of abuse. The antagonism is intensified by the difference in religion. This religious problem has not lessened with time. Owing to the growing number of Persians working in the province, mainly as Government officials, at the religiously significant times of the Shi'a year-particularly Muharram, a number of Shi' a äkhunds visit the province to cater for the Shi' ${ }^{-6}$ minority. Not only is the level of religious learning of the average visiting akhund often somewhat lower than that of the local Maulavi who has studied twelve years or more in Pakistan and India, but the äkhunds are encouraged to attempt to proselytize and scorn the Sunni masses by the fact that they are automatically part of the ruling Persian-government-official class, thus adding to it a religious exclusiveness. Further, the Amirs of the Qa'ināt have for some time taken a special and rather jealous interest in the province, and owing to the policy of the Shaukatu'l Mulk earlier in this century a large proportion of the civil servants there are Birjandi, ${ }^{32}$ and often related, and so tend to keep together more than they might otherwise, and further emphasize the exclusiveness of the class. The visible trade of the province is conducted mainly by Yazdīs and Kermānīs, who in some cases have acquired a considerable amount of local property, particularly around Khwāsh and Irānshahr. The administrative towns of Khwāsh, Irānshahr and Sarāvān are to a large extent run by these Persians. The generality of the Balūch have not really understood the use of towns and bazaars, and they look on helplessly, bereft of self-confidence, while the Persians supposedly attempt to run their country as though it were any other province of Persia. Backward or under-developed societies may be divided into two main groups: those which have at some point in their history passed through a stage of higher economic or cultural development than that of their present condition, and those who have not. The former would seem to include the Balūch.

3i There are, of course, exceptions to this: the most obvious being the resorts on the Caspian, and, at the nauriz $z$ season only, such places as $\bar{A} b \bar{b} \mathrm{dā} n$ and Tabas.
32 Cf. A. K. S. Lambton: Landlord and Peasant in Persia, Oxford University Press, I953, p. 266. 
They have passed a peak, unable to develop further on their own traditions. Rather, if their society and its physical environment are to be developed, it must be through the agency of some strong expanding neighbour which would cause a violent change or social revolution in them, or absorb them in its progress.

The essential things to the Balūch life are still the palm, the flock and the handmill; there can be no form of insurance that the next year or so will not be drought and kill off the flocks; and the garband is only marginal to the economy of the region where so much labour is being spent on it, and could never be otherwise. But what of their culture?

While literacy in the Balūch language (particularly in the Persian province) is practically nonexistent, Balūch music and poetry flourish still within the framework of firm traditions and with full popular support and participation. At least among the "mountain Balūch" the pride in the Balūch way of life, the outdoor life, is still strong: for instance, two of the most respected attainments are speed in long-distance walking and skill in weaving saväs-the palm-leaf sandals. The rules of hospitality and social intercourse are proudly kept in full. And it would be difficult to imagine Islam playing a fuller part in the life of the people.

So culture there certainly is. But, as we have noted, enterprise and readiness for development and social change are discouragingly rare. The number of Balūch who have made their mark outside the province is infinitesimal compared to other non-Persian provinces of Iran. And such a culture is of value only to its own people, and would appear in fact to have lost most of its force and be on the wane.

Leaving aside the social problems, the main areas of the province which would repay development are:

(a) The rich plain of İrānshahr-Bampūr;

(b) Dashtiārī (if a reasonable and regular water supply could be guaranteed);

(c) The coastal plain in the vicinity of Kahir (water from river and possible dam);

(d) The area of Pìshin;

(e) The Khwāsh plain in the sarhadd.

Apart from these areas certain centres on perennial rivers in the mountainous areas (e.g. Sarbāz, İafshān, etc.) could be developed for fruit growing. The remainder of the province, although in parts capable of supporting large flocks at times, owing to the capriciousness of the precipitation pattern, could never be economically secure. The two essential ingredients for the success of any development schemes in the area are a road network, and local self-confidence and initiative. The first is possible at a price. The second, in the present context of a hangover from the social hierarchy of the "Balūch period" and the lack of qualities of leadership in the majority of the sardārs, and the mutual suspicion and contempt between the Balūch and the Persians from whom they must learnpresents grave difficulties.

Thus Balūchistān suffers from a very large percentage of the possible drawbacks to any policy which would accept political and economic responsibilities for them. It can hardly be considered unfair to regard the province as a cul de sac not only from the point of view of the historical pattern of communications of Western Asia, ${ }^{33}$ but also its economic and cultural history.

The climate is to most people extremely unpleasant for six months of the year. It is doubtful whether the province could ever make a useful contribution to the economy of the country as a whole. Politically, it is hardly likely again to be either important or even embarrassing. Its only claim on the attention of the central government, or in fact the world in the latter half of the twentieth century, is that it is a black mark on its record of progress and therefore an embarrassment. Responsibility for it is very much moral and political, and since its condition is not unique in the world today, invokes a universal philosophy to bear it.

33 Cf. Toynbee, $s p$. cit., chapter I. 